\title{
EFFECT OF HOT RED PEPPER ON PRODUCTIVE PERFORMANCE AND CARCASS CHARACTERISTICS OF GROWING JAPANESE QUAIL
}

\author{
Haiam S. Abd EL-Haliem
}

Animal Production Department, Faculty of Agriculture, Suez Canal University, Ismailia, Egypt, P.O. Box41522, E-mail: haiam65@yahoo.com

Received: $16 / 7 / 2019$

Accepted: 28/8/2019

SUMMARY

This study was carried out to investigate the effect of hot red pepper (HRP) as a feed additive in growing quail diets on their growth performance and carcass characteristics. A total of 225 unsexed Japanese quails at 14 days old were randomly divided into five treatments, each treatment had three replicates of 15 birds. Chicks were fed basal diet as a control (T1) and HRP was added to the basal diet as $0.1 \%$ (T2), $0.2 \%$ (T3), $0.3 \%$ (T4), and $0.4 \%$ (T5).

Body weight gain, feed consumption and feed conversion ratio were calculated biweekly. At the end of the experiment, (6 weeks old), six birds (3 males and 3 females) from each treatment were chosen around the average body weight and slaughtered to evaluate carcass traits and economic assessments. With respect to the entire period studied (2-6 weeks old); results indicated that the inclusion of HRP in Japanese quail diets did not show any significant effect on body weight. Moreover, chicks fed diet containing $0.2 \%$ HRP had insignificantly $(P \leq 0.05)$ the heaviest body weight and body weight gain. Also, chicks fed diets with 0.3 or $0.4 \%$ $H R P$ recorded significant $(P \leq 0.05)$ lower feed intake than other treatments. Also, birds fed $0.2 \%$ HRP diets utilized feed more efficiently and mortality tended to be significantly lower (6.67\%) than birds fed on the other treatment diets. Dressing and carcass relative weights of the same group $(0.2 \%$ HRP) were more $(P \leq 0.05)$ than those fed other diets. The results indicated that the most economical treatment was obtained when $0.2 \%$ HRP was added to the diet where best economic efficiency (1.93) and relative economic efficiency (107.49) were achieved. It was concluded that using HRP as feed additive at $0.2 \%$ had a beneficial effect on the overall performance of growing Japanese quail chicks.

\section{Keywords: hot red pepper; carcass characteristics; Japanese quail; feed additives}

\section{INTRODUCTION}

Hot red pepper belongs to a family of Solanaceae whose Latin name is Capsicum annuum. Hot or chili pepper (Paprika) has terpenoid compound capsaicin, which has antibacterial properties. The numerous terpenoids in different herbs have a high antioxidant function (Nakatani, 1994). The substances that give hot peppers their heat is capsaicin plus some related chemicals called combined capsinoids (El-Tazi, 2014a).

The addition of garlic, black pepper and hot red pepper in broiler chicken dietshas a beneficial impact on productive performance (Puvača, et al., 2019). Also, Adedoyin et. al. (2019) noted that Anak broiler chicks fed diets supplemented with HRP at levels $1.0 \%, 1.25 \%$ and $1.50 \%$ had numerically higher average feed intake and average body weight gain compared to the control. Also, Divya (2017) noted that black pepper can be integrated as a natural feed additive up to $1.0 \%$ level in the diet of quails without any adverse effect on productive performance.

Sayeed et al. (2016) reported that feeding quail diets containing red pepper at a level of $2 \%$ may have beneficial effects on performance and blood metabolites. Shahverdi et al. (2013) found that the use of herbal mixtures in bird diets has achieved inconsistent results when broiler chicks were fed diets with $0.02 \%$ red pepper, (T1), $0.02 \%$ black pepper, (T2) and $0.01 \%$ red pepper $+0.01 \%$ black pepper powders.

Al-Kassie et al. (2011) reported that the use of hot red pepper as a feed additive at $0.50 \%, 0.75 \%$ and $1 \%$ enhance the overall performance of broiler chicks. Also, El-Ghamry et al. (2004) reported that hot pepper is a good natural feed additive for improving the performance of Muscovy ducklings.

Furthermore, Al-Harthi (2002b) found that broiler chicks fed hot pepper containing-diet had improved growth and FCR. El-Husseiny et al. (2002) found that broiler chicks fed hot pepper had significantly higher body weight, dressing percentage than those fed the control or fenugreek diets. On the other hand, Vogt et al. (1989) found that spices such as cayenne (hot) pepper, coriander, white pepper did not affect gain; however, hot pepper at $100 \mathrm{mg} / \mathrm{kg}$ diet improved FCR by $3.2 \%$.

This work aimed to evaluate hot red pepper as a feed additive in growing Japanese quail diets on their growth performance and carcass characteristics.

\section{MATERIALS AND METHODS}

\section{Management and treatments}

The current work was carried out at the Poultry Farm, Faculty of Agriculture, Suez Canal University, Ismailia, Egypt.

A total of 225 unsexed Japanese quails at 14 days old with an average weight of $30.2 \pm 1.0 \mathrm{~g}$ were wing- 
banded and randomly divided into five experimental treatments, each treatment had three replicates of 15 birds. The chicks were kept under normal brooding battery conditions with wire mesh floors. The artificial light was provided 24 hours a day.

The experimental treatments were basal diet as the control group (T1), and red hot pepper (HRP) was added to the basal diet as $0.1 \%$ (T2), $0.2 \%$ (T3), 0.3 $\%$ (T4), and $0.4 \%$ (T5).

Experimental basal diet (Table 1) was composed to meet the nutrient requirements of the growing Japanese quail chicks at this age according to (NRC, 1994). Feed and water were given to birds ad libitum during the whole trial period.

Table 1. Composition and calculated analysis of the basal diet fed to experimental birds

\begin{tabular}{lc}
\hline Ingredients & $\%$ \\
\hline Yellow corn & 56.2370 \\
Soybean meal 44\% & 33.8739 \\
Gluten $(60 \%)$ & 7.0213 \\
Di-calcium phosphate & 0.8327 \\
Limestone & 1.1922 \\
Salt & 0.32 \\
Vit. + Min. mixture* & 0.30 \\
L- Lysine & 0.2229 \\
Total & 100.00 \\
Calculated analysis & \\
ME(Kcal/kg) & 2900.52 \\
Crude protein & 24.04 \\
Calcium & 0.80 \\
Available phosphorus & 0.30 \\
Methionine & 0.42 \\
Lysine & 1.35 \\
Methionine+ Cysteine & 0.82 \\
\hline * Vit. + Min. mixture: each 1 kg contains: Vit. A: 10.000 .000 IU, Vit. D1:3.000.000 IU, Vit. H: 10.000 mg, Vit. k3:1000 mg, \\
Vit. B1: 1000 mg, Vit. B3: 5000 mg, Vit. B6: 1500 mg, Vit. B12: 10 mg, Biotin: 50 mg, Pantothenic acid: 10.000 mg, \\
Niacin: 30.000 mg, Folic acid 1000 mg, Choline chloride: 350.000 mg, manganese sulfate: 60.000 mg, Zinc oxide: 50.000 \\
mg, Ferric sulfate: 30.000 mg, Copper sulfate: 4000 mg, Potassium Iodide: 300 mg and Cobalt sulfate 100 mg.
\end{tabular}

All chicks were kept under the same management, en vironmental and health conditions. Birds' body weight per group was recorded at biweekly intervals on an individual basis.

Also, the cumulative feed consumption per group was recorded biweekly. Feed conversion ratio per group was estimated at biweekly intervals by taking into consideration the biweekly body weight gain and the feed consumption of a respective group.

The mortality rate of the experimental birds was carefully observed and recorded daily. Dietary nutrients were determined by chemical analysis (AOAC, 1995).

At the end of the $6^{\text {th }}$ week, six birds ( 3 males and 3 females) from each treatment were chosen around the average body weight and slaughtered after 12 hours fasting period. After complete bleeding and feather removal, the carcass organs were manually eviscerated and weighed. The percentages of the carcass, dressing (eviscerated carcass without head and legs + giblets weight), edible giblets (liver, gizzard and heart) and offals (blood, viscera, legs, head, spleen and feathers) were calculated in relation to the live body weight.

\section{Economic Efficiency Analysis (EEA)}

The economic efficiency (\%) was calculated on the basis of input-output analysis based upon the differences in both growth rate and feeding costs and was determined by the following formula:
Economic efficiency $\%=$ Net revenue $/$ Total feed cost)* 100

Data were statistically analyzed using SAS ${ }^{\circledR}$ software computer program (SAS, 2006) and the significant differences among means were detected according to Duncan (1955).

\section{RESULTS AND DISCUSSION}

\section{Productive performance:}

The effect of assorted levels of HRP as a feed additive on the growth performance of Japanese quail chicks is presented in Table (2). No significant differences in body weights at the start of the study between all groups (14-d of age). Around a month old (four weeks old), birds eating a $0.2 \%$ HRP diet had significantly $(\mathrm{P} \leq 0.05)$ greater live body weight. At the end of the trial ( 6 weeks old), body weight was significantly impacted by adding HRP to the experimental diets. Whilst the group fed diet supplemented with $0.2 \%$ HRP had the heaviest body weight among the experimental groups. These results are similar to those of Rahimian et al. (2018) who noted that a significant improvement in body weight when quail diets were supplemented with ginger, red and black pepper and protexin at level $2 \%$ compared to control. This outcome is in harmony with Sayeed et al. (2016) who found that body weight (g) was significantly higher when the quail chicks fed diets with $2 \%$ of each ginger, red pepper or black pepper 
compared to control. Also, Puvača et al. (2015) reported that adding garlic and HRP to broiler feed of the amount $0.5 \mathrm{~g} / 100 \mathrm{~g}$ resulted in higher final body weights. Similarly, Shahverdi et al. (2013) showed that chicks fed diets with red pepper $(0.02 \%)$, black pepper $(0.02 \%)$ and mixed powders $(0.01 \%$ red pepper $+0.01 \%$ black pepper powders) had a higher body weight $(\mathrm{P} \leq 0.05)$ compared to the control group.

Table 2. Effect of red hot pepper as a feed additive on the performance of growing Japanese quails $(\mathrm{X} \pm \mathrm{SE})$

\begin{tabular}{|c|c|c|c|c|c|c|c|}
\hline \multirow{3}{*}{ Item } & \multirow{3}{*}{$\begin{array}{c}\text { Age } \\
\text { (weeks) }\end{array}$} & \multicolumn{6}{|c|}{ Treatments } \\
\hline & & \multirow{2}{*}{ Control } & \multicolumn{4}{|c|}{ Red hot pepper level \% } & \multirow{2}{*}{ Sig. } \\
\hline & & & 0.1 & 0.2 & 0.3 & 0.4 & \\
\hline \multirow[t]{6}{*}{ Body weight (gm) } & 2 & 30.11 & 29.70 & 29.97 & 31.08 & 30.47 & NS \\
\hline & & \pm 1.07 & \pm 0.77 & \pm 0.88 & \pm 1.14 & \pm 1.13 & \\
\hline & 4 & $103.53^{\mathrm{ab}}$ & $102.67^{\mathrm{ab}}$ & $111.42^{\mathrm{a}}$ & $103.47^{\mathrm{ab}}$ & $98.50^{\mathrm{b}}$ & * \\
\hline & & \pm 2.98 & \pm 2.81 & \pm 2.39 & \pm 3.77 & \pm 2.92 & \\
\hline & 6 & 175.99 & 174.14 & 180.19 & 175.02 & 177.60 & NS \\
\hline & & \pm 2.76 & \pm 2.37 & \pm 2.61 & \pm 4.06 & \pm 3.20 & \\
\hline \multirow[t]{6}{*}{ Body gain (gm) } & 2 to 4 & $73.42^{b}$ & $72.97^{\mathrm{b}}$ & $81.45^{\mathrm{a}}$ & $72.39^{\mathrm{b}}$ & $68.03^{b}$ & * \\
\hline & & \pm 2.36 & \pm 2.39 & \pm 2.02 & \pm 3.03 & \pm 2.02 & \\
\hline & 4 to 6 & $72.46^{\mathrm{b}}$ & $71.48^{\mathrm{b}}$ & $68.78^{\mathrm{b}}$ & $71.55^{\mathrm{b}}$ & $79.10^{\mathrm{a}}$ & $*$ \\
\hline & & \pm 1.63 & \pm 1.31 & \pm 1.04 & \pm 1.33 & \pm 1.21 & \\
\hline & 0 to 6 & 145.88 & 144.45 & 150.23 & 143.94 & 147.14 & NS \\
\hline & & \pm 2.16 & \pm 1.99 & \pm 2.33 & \pm 3.36 & \pm 2.34 & \\
\hline \multirow[t]{6}{*}{ Feed intake (gm) } & 2 to 4 & $184.80^{\mathrm{a}}$ & $184.54^{\mathrm{a}}$ & $175.29^{b}$ & $183.66^{\mathrm{a}}$ & $165.78^{c}$ & $*$ \\
\hline & & \pm 3.13 & \pm 1.53 & \pm 0.26 & \pm 2.41 & \pm 1.33 & \\
\hline & 4 to 6 & $308.75^{\mathrm{a}}$ & $309.03^{\mathrm{a}}$ & $308.14^{\mathrm{a}}$ & $292.79^{b}$ & $309.40^{\mathrm{a}}$ & $*$ \\
\hline & & \pm 2.45 & \pm 7.16 & \pm 5.47 & \pm 3.16 & \pm 2.99 & \\
\hline & 0 to 6 & $493.55^{\mathrm{a}}$ & $493.56^{\mathrm{a}}$ & $483.43^{\mathrm{ab}}$ & $476.44^{b}$ & $475.18^{b}$ & $*$ \\
\hline & & \pm 2.23 & \pm 6.31 & \pm 5.37 & \pm 3.94 & \pm 1.97 & \\
\hline \multirow{6}{*}{$\begin{array}{l}\text { Feed conversion, } \\
\text { (g feed/g gain) }\end{array}$} & 2 to 4 & $2.52^{\mathrm{a}}$ & $2.53^{\mathrm{a}}$ & $2.15^{\mathrm{b}}$ & $2.54^{\mathrm{a}}$ & $2.44^{\mathrm{a}}$ & $*$ \\
\hline & & \pm 0.07 & \pm 0.10 & \pm 0.07 & \pm 0.09 & \pm 0.08 & \\
\hline & 4 to 6 & $4.26^{\mathrm{ab}}$ & $4.32^{\mathrm{ab}}$ & $4.48^{\mathrm{a}}$ & $4.09^{b c}$ & $3.91^{\mathrm{c}}$ & $*$ \\
\hline & & \pm 0.09 & \pm 0.17 & \pm 0.09 & \pm 0.09 & \pm 0.09 & \\
\hline & 0 to 6 & $3.38^{\mathrm{ab}}$ & $3.42^{\mathrm{a}}$ & $3.22^{\mathrm{b}}$ & $3.31^{\mathrm{ab}}$ & $3.23^{\mathrm{ab}}$ & $*$ \\
\hline & & \pm 0.05 & \pm 0.05 & \pm 0.05 & \pm 0.07 & \pm 0.06 & \\
\hline \multirow[t]{6}{*}{ Mortality rate (\%) } & 2 to 4 & 8.89 & 11.11 & 2.22 & 8.89 & 8.89 & NS \\
\hline & & \pm 2.22 & \pm 2.22 & \pm 2.22 & \pm 4.44 & \pm 2.22 & \\
\hline & 4 to 6 & 6.67 & 2.22 & 2.22 & 4.45 & 2.22 & NS \\
\hline & & \pm 0.0 & \pm 2.22 & \pm 2.22 & \pm 2.22 & \pm 2.22 & \\
\hline & 0 to 6 & $15.55^{\mathrm{ab}}$ & $13.33^{\mathrm{ab}}$ & $6.67^{b}$ & $15.55^{\mathrm{ab}}$ & $17.78^{\mathrm{a}}$ & $*$ \\
\hline & & \pm 2.22 & \pm 3.85 & \pm 3.85 & \pm 2.22 & \pm 2.22 & \\
\hline
\end{tabular}

$\overline{\mathrm{a}, \mathrm{b}, \mathrm{c}}$ Values in the same row with a different superscript differ significantly at $\mathrm{p}<0.05 . \quad \mathrm{NS}=$ Not significant

Data presented in Table (2) revealed that body weight gain of chicks during periods from $2-4$ and 4 6 weeks old was significantly $(\mathrm{P} \leq 0.05)$ influenced. Although body weight gain during the period (2-6 weeks old), was not significantly $(\mathrm{P} \leq 0.05)$ affected. It can be noted that the best body weight gain was in the group fed diet with $0.2 \%$ HRP during the first period studied (2-4 weeks old), while, during the second period studied (4-6 weeks old) the best body weight gain was observed in a group fed diet with $0.4 \%$ HRP than the other treatment groups. For the whole period studied (2-6 weeks) chicks fed diet containing $0.2 \%$ HRP had insignificantly $(\mathrm{P} \leq 0.05)$ the highest body weight gain. While, Divya (2017) showed that body weight gain increased significantly $(\mathrm{P} \leq 0.05)$ by increasing the amount of black pepper in the diet of quail chicks from 0.0 to $1.0 \%$. Also,
Valiollahi et al. (2014) fed chicks a basal diet as a control group (T1), basal diet with $0.02 \%$ ginger powder (T2), basal diet with $0.02 \%$ black pepper powder (T3) and basal diet with $0.01 \%$ ginger + $0.01 \%$ black pepper powder (T4) and showed that body weight and body weight gain at the end of the experiment were significantly higher in the treated groups compared to the control. Also, Tollba et al. (2007) found that supplementation of bio-antioxidant (hot pepper) to the diet of the Egyptian chicken at level $5 \mathrm{~g} / \mathrm{kg}$ diet improved $(\mathrm{P} \leq 0.05)$ body weight gain as compared with the control. By contrast, with őzer et al. (2006) who reported low-dose HRP added to the cock diet during the developmental period ( 5 months) could reduce body weight gain. This irregularity might be a result of the variations within the quantity of spices. 
As illustrated in Table (2), the feed intake among experimental groups varied significantly.

A significant reduction in the feed intake values was found in groups fed diets supplemented with 0.2 and $0.4 \%$ HRP during the first period (2-4 weeks of age). Furthermore, there was a significant $(\mathrm{P} \leq 0.05)$ reduction in feed intake value in a group fed diet of $0.3 \mathrm{HRP}$ in the second period (4-6 weeks of age) of this research. Feed intake for the whole experimental period revealed that groups fed diets supplemented with 0.3 or $0.4 \%$ HRP was significantly $(\mathrm{P} \leq 0.05)$ lower than that of the other groups.

This may be because of the change in feed taste as reported by Sturkie (1986) who concluded that birds have a sense of taste. The reason for decreased feed intake with the addition of black pepper in diet might be because of strong and spicy flavor resulting in the reduce palatability of the feed (Windisch, et. al., 2008). These results are in line with findings of Divya (2017) who reported that the feed intake reduced significantly $(\mathrm{P} \leq 0.01)$ with increased level of black pepper incorporation up to $1.0 \%$ in the quail diet as compared to those fed the control diet during the experimental period. Similarly, Ndelekwute et al. (2015) who noted that feed intake reduced significantly $(\mathrm{P} \leq 0.05)$ when black pepper was added up to $1 \%$ in broiler diets. As well, Soliman (2002) reported that red pepper gave the minimum $(\mathrm{P} \leq 0.05)$ feed intake by 9.48 and $8.03 \%$ of the control for 1.5 and $3 \%$ red pepper, respectively. Also, Al-Harthi (2002a) showed that the broiler chicks fed diet supplemented with $0.3 \%$ HRP decreased FI. On the other hand, Adedoyin et al. (2019) found that birds fed diets supplemented with the hot red pepper (HRP) had numerically higher average feed intake compared to the control. Also, Sayeed et al. (2016) stated that the use of protexin and herbals increased feed intake $(\mathrm{g})$ significantly $(\mathrm{P} \leq 0.05)$ compared to control.

Significant differences $(\mathrm{P} \leq 0.05)$ in FCR among treatments during all periods studied (Table 2). With respect to the entire period of experiment studied (26 weeks); the birds fed on $0.2 \%$ HRP diets utilized the feed more efficiently than birds fed on the other diets. Also, Puvača et al. (2019) revealed that adding garlic, black pepper and HRP and their mixture to broiler diets has a positive effect on feed utilization. Similarly, El-Tazi (2014b) revealed that incorporation of capsaicin in the diet at levels of 0.5 , 0.75 and $1 \%$ significantly improve feed conversion ratio of broiler chicks. Also, Adedoyin et al. (2019) and Al-Kassie et al. (2011) decided that the supplementation of HRP in the diet improved feed conversion ratio.

Vogt et al. (1989) found that supplementary hot pepper at $100 \mathrm{mg} / \mathrm{kg}$ diet improved feed conversion ratio by $3.2 \%$. While El-Harthi (2002a) noted that hot pepper at $0.1 \%$ insignificantly improved broiler feed conversion ratio by $8.3 \%$ compared to the control diet.

Mortality tended to be significantly lower (6.67\%) on a diet containing $0.2 \%$ HRP. While, mortality was higher in groups containing $0.1,0.3$ and $0.4 \% \mathrm{HRP}$ and control groups $(13.33,15.55$, 17.78 and $15.55 \%$, respectively).

While, El-Tazi (2014a) revealed that a combination of red and black pepper powder $(0.5 \%$ red pepper $+0.5 \%$ black pepper) in broiler diet had no significant impact on mortality rate. Whereas, Soliman (2002) found that red pepper at 1.5 or $3 \%$ improved the viability of the birds especially when added to the low energy diets. However, El-Husseiny et al. (2002) reported that broiler mortality rates were within the normal range of diets with different red pepper levels $(1.0,1.5$ or $2.0 \%$, not exceeding $5 \%$.

Due to the addition of HRP significant variations $(\mathrm{P} \leq 0.05)$ were detected in dressing, carcass and offal relative weights (Table 3 ). The carcass relative weights and dressing of the group fed diet with $0.2 \%$ HRP were heavier $(\mathrm{P} \leq 0.05)$ than those fed other treatment diets.

El-Tazi, (2014a) showed a significantly $(\mathrm{P} \leq 0.05)$ higher percentage of dressing in the diet with $1 \%$ mixture powder of red and black pepper. Also, AlKassie et al. (2011) stated that the incorporation of a mixture of HRP and black pepper at a rate of 0.75 and $1 \%$ in the diets mends significantly $(\mathrm{P} \leq 0.05)$ the proportions of broilers dressing.

Similarly, a significant enhancement $(\mathrm{P} \leq 0.05)$ in the dressing and relative weights of the giblets compared to the control noted when HRP is adding to the Egyptian Golden Montazah chicks diet at 0.5\% (Tollba et al., 2007). On the contrary, Al-Harthi (2002a) did not find any effect on carcass traits when broilers fed diets containing 0.1 or 0.2 or $0.3 \%$ HRP.

In this research, irrespective of treatments, there were no significant differences in carcass traits due to sex except for liver relative weight, where, the female birds had a significantly higher $(\mathrm{P} \leq 0.05)$ liver relative weight than the male birds. Khalil et al. (2007) also discovered that female quail birds had a significantly higher giblets weight $\%$ than the male birds. 
Table 3. Effect of red hot pepper as a feed additive on some carcass characteristics of growing Japanese quails $(\mathrm{X} \pm \mathrm{SE})$

\begin{tabular}{|c|c|c|c|c|c|c|c|}
\hline \multirow[t]{2}{*}{ Items } & \multirow[t]{2}{*}{ Sex } & \multicolumn{5}{|c|}{$\begin{array}{l}\text { Treatments } \\
\text { Red hot pepper \% }\end{array}$} & \multirow[t]{2}{*}{ Overall } \\
\hline & & & 0.1 & 0.2 & 0.3 & 0.4 & \\
\hline \multirow{4}{*}{$\begin{array}{l}\text { Live body weight } \\
\text { (g) }\end{array}$} & Male & $180.34 \pm 4.34$ & $174.16 \pm 9.59$ & $188.06 \pm 1.25$ & $189.98 \pm 3.75$ & $174.59 \pm 3.47$ & $181.43 \pm 2.66$ \\
\hline & Femalea & $175.06 \pm 1.44$ & $179.31 \pm 3.72$ & $176.40 \pm 6.81$ & $165.18 \pm 1.09$ & $184.61 \pm 5.56$ & $176.11 \pm 2.37$ \\
\hline & Overall & $177.69 \pm 2.36$ & $176.73 \pm 4.74$ & $182.23 \pm 4.05$ & $177.58 \pm 5.81$ & $179.61 \pm 3.69$ & \\
\hline & Male & $75.82 \pm 0.84$ & $76.95 \pm 2.19$ & $79.25 \pm 3.11$ & $75.27 \pm 2.97$ & $75.25 \pm 0.35$ & $76.51 \pm 0.92$ \\
\hline \multirow[t]{3}{*}{ Dressing $\%^{1}$} & Female & $74.08 \pm 0.99$ & $73.32 \pm 1.43$ & $81.36 \pm 1.43$ & $74.31 \pm 1.61$ & $75.30 \pm 0.23$ & $75.67 \pm 0.91$ \\
\hline & Overall & $74.95 \pm 0.69^{\mathrm{b}}$ & $75.14 \pm 1.43^{\mathrm{b}}$ & $80.30 \pm 1.60^{\mathrm{a}}$ & $74.79 \pm 1.53^{\mathrm{b}}$ & $75.27 \pm 0.19^{\mathrm{b}}$ & \\
\hline & Male & $72.06 \pm 0.95$ & $73.26 \pm 2.05$ & $75.74 \pm 3.05$ & $72.64 \pm 2.86$ & $71.82 \pm 0.12$ & $73.10 \pm 0.88$ \\
\hline \multirow[t]{3}{*}{ Carcass $\%^{2}$} & Female & $70.71 \pm 0.78$ & $68.93 \pm 1.72$ & $77.67 \pm 1.66$ & $69.72 \pm 2.19$ & $71.87 \pm 0.98$ & $71.78 \pm 1.02$ \\
\hline & Overall & $71.38 \pm 0.63^{\mathrm{b}}$ & $71.14 \pm 1.54^{\mathrm{b}}$ & $76.71 \pm 1.61^{\mathrm{a}}$ & $71.18 \pm 1.74^{\mathrm{b}}$ & $71.84 \pm 0.44^{\mathrm{b}}$ & \\
\hline & Male & $2.17 \pm 0.25$ & $2.35 \pm 0.14$ & $2.26 \pm 0.44$ & $1.91 \pm 0.15$ & $2.28 \pm 0.14$ & $2.19 \pm 0.10^{\mathrm{B}}$ \\
\hline \multirow[t]{3}{*}{ Liver \% } & Female & $2.15 \pm 0.12$ & $3.22 \pm 0.35$ & $2.48 \pm 0.08$ & $2.75 \pm 0.56$ & $2.52 \pm 0.53$ & $2.62 \pm 0.17^{\mathrm{A}}$ \\
\hline & Overall & $2.16 \pm 0.12$ & $2.79 \pm 0.26$ & $2.37 \pm 0.21$ & $2.33 \pm 0.32$ & $2.39 \pm 0.25$ & \\
\hline & Male & $0.96 \pm 0.3$ & $0.81 \pm 0.04$ & $0.84 \pm 0.21$ & $0.92 \pm 0.11$ & $0.88 \pm 0.03$ & $0.88 \pm 0.04$ \\
\hline \multirow[t]{3}{*}{ Heart \% } & Female & $0.86 \pm 0.05$ & $0.92 \pm 0.08$ & $0.90 \pm 0.04$ & $0.72 \pm 0.11$ & $0.89 \pm 0.02$ & $0.86 \pm 0.03$ \\
\hline & Overall & $0.91 \pm 0.04$ & $0.86 \pm 0.05$ & $0.87 \pm 0.09$ & $0.82 \pm 0.09$ & $0.89 \pm 0.02$ & \\
\hline & Male & $2.26 \pm 2.42$ & $2.1 \pm 0.25$ & $1.93 \pm 0.15$ & $1.68 \pm 0.10$ & $1.83 \pm 0.02$ & $1.96 \pm 0.10$ \\
\hline \multirow[t]{3}{*}{ Empty gizzard \% } & Female & $1.96 \pm 0.24$ & $1.83 \pm 0.16$ & $2.05 \pm 0.05$ & $2.37 \pm 0.14$ & $1.69 \pm 0.19$ & $1.98 \pm 0.09$ \\
\hline & Overall & $2.11 \pm 0.23$ & $1.96 \pm 0.15$ & $1.99 \pm 0.07$ & $2.02 \pm 0.17$ & $1.77 \pm 0.09$ & \\
\hline & Male & $5.39 \pm 0.67$ & $5.26 \pm 0.18$ & $5.03 \pm 0.09$ & $4.50 \pm 0.31$ & $4.99 \pm 0.13$ & $5.03 \pm 0.15$ \\
\hline \multirow[t]{3}{*}{ Giblets $\%^{3}$} & Female & $4.97 \pm 0.21$ & $5.97 \pm 0.22$ & $5.43 \pm 0.09$ & $5.84 \pm 0.44$ & $5.11 \pm 0.69$ & $5.46 \pm 0.18$ \\
\hline & Overall & $5.18 \pm 0.33$ & $5.61 \pm 0.20$ & $5.23 \pm 0.11$ & $5.17 \pm 0.38$ & $5.05 \pm 0.32$ & \\
\hline & Male & $24.18 \pm 0.83$ & $23.05 \pm 2.19$ & $20.75 \pm 3.11$ & $24.73 \pm 2.97$ & $24.75 \pm 0.35$ & $23.49 \pm 0.92$ \\
\hline \multirow[t]{2}{*}{ Offals $\%{ }^{4}$} & Female & $25.92 \pm 0.83$ & $26.68 \pm 1.43$ & $18.64 \pm 1.43$ & $25.69 \pm 1.61$ & $24.70 \pm 0.23$ & $24.33 \pm 0.91$ \\
\hline & Overall & $25.04 \pm 0.69^{\mathrm{a}}$ & $24.87 \pm 1.42^{\mathrm{a}}$ & $19.69 \pm 1.60^{\mathrm{b}}$ & $25.21 \pm 1.53^{\mathrm{a}}$ & $24.73 \pm 0.19^{\mathrm{a}}$ & \\
\hline
\end{tabular}

\section{Economic Efficiency:}

Results of economic efficiency (EEF) for quails fed the experimental diets during the growth period (14-42 days) are summarized in Table (4). The results showed that the most economical treatment was achieved by adding $0.2 \%$ HRP to the diet where it gave the best EE (1.93) and relative EE (107.49). This result might be due to that level $(0.2 \%$ HRP) gave higher body weight gain and feed conversion than other levels of HRP and the control diet. El-
Tazi, (2014a) reported that treatment with $1 \%$ mixture powder level $(0.5 \%$ red pepper $+0.5 \%$ black pepper) showed the highest profitability ratio (1.81) compared to the control group. While, Al-Harthi (2002b) indicated that hot pepper at $0.1 \%$ insignificantly improved economic efficiency by $8.1 \%$ compared to the control diet. Whereas, Soliman (2002) revealed that $1.5 \%$ red pepper gave the highest of EEF and REEF values.

Table 4. The economical efficiency of the experimental diets

\begin{tabular}{lccccc}
\hline & \multicolumn{5}{c}{ Treatments } \\
\cline { 2 - 6 } Items & \multirow{2}{*}{ Control } & \multicolumn{3}{c}{ Red hot pepper \% } \\
\cline { 3 - 6 } & & $\mathbf{0 . 1}$ & $\mathbf{0 . 2}$ & $\mathbf{0 . 3}$ & $\mathbf{0 . 4}$ \\
\hline Average feed consumed (kg/ quail) & 0.49355 & 0.49356 & 0.48343 & 0.47644 & 0.47518 \\
Price/kg feed consumed (LE) & 6.3500 & 6.3600 & 6.3700 & 6.3800 & 6.3900 \\
Total feed cost (LE) & 3.1340 & 3.1390 & 3.0794 & 3.0397 & 3.0364 \\
Body weight gain (kg/quail) & 0.14588 & 0.14445 & 0.15023 & 0.14394 & 0.14714 \\
Price /kg LBW(LE) & 60.0 & 60.0 & 60.0 & 60.0 & 60.0 \\
BWG revenue (LE) & 8.7528 & 8.6670 & 9.0138 & 8.6364 & 8.8284 \\
Net revenue (LE) & 5.6188 & 5.5280 & 5.9344 & 5.5967 & 5.7920 \\
Economic efficiency 3 & 1.7929 & 1.7611 & 1.9271 & 1.8412 & 1.9075 \\
Relative economic efficiency (\%) 4 & 100.00 & 98.23 & 107.49 & 102.69 & 106.39 \\
\hline
\end{tabular}

${ }^{1} \mathrm{LE}=$ Egyptian pound. $\quad{ }^{2}$ Net revenue $=\mathrm{BWG}$ revenue - Total feed cost.

${ }^{3}$ Economic efficiency $=$ Net revenue $/$ Total feed cost.

${ }^{4}$ Relative economic efficiency, assuming the control treatment $=100 \%$.

\section{CONCLUSION}

It can be concluded that the addition of HRP in the growing Japanese quail chicks diet by $0.2 \%$ was sufficient to improve growth performance, carcass characteristics and economic efficiency. More researches are needed to further clarify the mechanisms associated with these valuable impacts.

\section{REFERENCE}

Adedoyin, A. A., M. A. Mosobalaje and A. I. Bamimore, 2019. Performance, immuno- 
stimulatory and blood biochemical indices of broiler chickens fed hot red pepper (Capsicum annuum L.) supplemented diets. Journal of Experimental Agriculture International. 36, (3) 18.

Al-Harthi, M.A. 2002a. Performance and carcass characteristics of broiler chicks as affected by different dietary types and levels of herbs and spices as no classical growth promoters. Egypt. Poult. Sci., 22, 325-343.

Al-Harthi, M.A. 2002b. Efficacy of vegetable diets with antibiotics and different type of spices or their mixtures on performance, economic efficiency and carcass traits of broilers. J. Agri. Sci. Mansoura University, 27, 3531-3545.

Al-Kassie, G.A.M., M.A.M. AL-Nasrawi and S.J. Ajeena. 2011. The effects of using hot red pepper as a diet supplement on some performance traits in broiler. Pakistan Journal of Nutrition 10, (9) 842-845.

A.O.A.C. 1990. Association of Official Analytical Chemists. Official Methods of Analysis, $15^{\text {th }}$ Edition. Washington, DC, USA.

Divya, V. S. 2017. Effect of black pepper (piper nigrum) as natural feed additive on the performance of Japanese quail. M.V. Sc. Fac. of Vet. Sci., Sri Venkateswara Vet. Univ., India.

Duncan, D.B. 1955. Multiple range and multiple F test. Biometrics, 11, (1) 1-42.

El-Ghamry, A. A., H.M. Azouz and A.T. Elyamny. 2004. Effect of hot pepper and fenugreek seed supplementation to low energy diets on Muscovy duckling performance. Egypt. Poult. Sci 24, (III) 613-627.

El-Husseiny, O., S.M. Shalash and H.M. Azouz. 2002. Response of broiler performance to diets containing hot pepper and/or fenugreek at different metabolizable energy level. Egypt Poult. Sci. 22, 387-406.

El-Tazi, S.M.A. 2014a. Response of broiler chicken to diets containing different mixture powder levels of red pepper and black pepper as natural feed additive. Animal and Vet. Sci.2, (3) 81- 86.

El-Tazi, S.M.A. 2014b . Response of broiler chicks to diet containing Capsaicin as natural feed additive. J. of Sci. and Tech., Omdurman Islamic Uni.4 (5) 81-86.

Khalil, H.A., A.M. Attia Faten, H.S. Abd Elhalim and M.E. Mady. 2007. Efficacy of dietary garlic under hot weather in Japanese quail. Egypt Poult. Sci. 27, (III) 645-661.

Nakatani, N. 1994. Antioxidative and Antimicrobial Constituents of Herbs and Spices. In Spices, Herbs and Edible Fungi. Elsevier Science, 34, 251-271.

National Research Council, NRC. 1994. Nutrient Requirements of Poultry. $9^{\text {th }}$ revised ed. National Academic Press. Washington, DC. USA

Ndelekwute, E., K. Afolabi, H. Uzegbu, U. Unah and K. Amaefule. 2015. Effect of dietary black pepper (Piper nigrum) on the performance of broiler. Bangladesh Journal of Animal Science, 44, (2) 120-127.

Özer, A., B. Zik, H. Erdost and N. Özfülüz, 2006. Histological investigations on the effects of feeding with a diet containing red hot pepper on the reproductive system organs of the cock. Turk J Vet Animal Sci 30, 7-15.

Puvača, N., D. Ljubojević, I. Čabarkapa, S. Popović, Z. Tomičić, N. Nikolova and J. Lević. 2019. Quality of broiler chickens carcass fed dietary addition of garlic, black pepper and hot red pepper. Journal of Agronomy, Technology and Engineering Management. Vol. 2, (1) 218-227.

Puvača, N., Lj. Kostadinović, D. Ljubojević, D. Lukač, J. Lević, S. Popović, N. Novakov, B. Vidović and O. Duragić. 2015. Effect of garlic, black pepper and hot red pepper on productive performances and blood lipid profile of broiler chickens. Europ. Poult. Sci. 79, ISSN 1612-9199.

Rahimian, Y., F. Kheiri and M. Moghaddam. 2018. Effect of using ginger, red and black pepper powder as phytobiotics with Protexin ${ }^{\circledR}$ probiotic on performance, carcass characteristics and some blood biochemical on Japanese quails (Coturnix japonica). Veterinary Science Development. Vol. 8 (1) 4-7.

SAS. 2006. Statistical Analysis System, SAS User's Guide: Statistics. SAS Institute Inc. Editors, Cary, $\mathrm{NC}$.

Sayeed, M.D, R. Yaser, R. Esfandiar, M. Hamzeh, Y. Mehrdad and D.P. Abbas. 2016. Effect of using ginger, red and black pepper powder as phytobiotics with protexin ${ }^{\circledR}$ probiotic on performance, carcass characteristics and some blood biochemical on Japanese quails. Scholarly Journal of Agricultural Science Vol. 6, (4) 120125.

Shahverdi, A., F. Kheiri, M. Faghani, Y. Rahimian and A. Rafiee. 2013. The effect of use red pepper (Capsicum annum L.) and black pepper (Piper nigrum L.) on performance and hematological parameters of broiler chicks. Euro. J. Zool. Res. 2 , (6) 44-48.

Soliman, A.Z.M. 2002. The bioefficacy of hot red pepper in practical layer diets varying in their energy content. Egypt Poult. Sci., 22, 1047-1062.

Sturkie, P.D. 1986. "Avian Physiology". $4^{\text {th }}$ ed. Springer-Verlag, Inc., New Work, NY.

Tollba, A.A.H., H.M.M. Azouz and M.H. AbdSamad. 2007. Antioxidants supplementation to diet of Egyptian chicken under different environmental condition: 2- The growth during cold winter stress. Egypt Poult. Sci., 27, 727-748.

Valiollahi, M.R., Y. Rahimian, Y. Miri, F. Asgarian, and A. Rafiee. 2014. Effect of ginger (Zingiber officinale) and black pepper (Piper nigrum L.) powder on performance, hematological parameters and antibody titre in broiler chicks. Research Opinions in Animal and Veterinary Sciences, 4, (3) 128-132. 
Vogt, H., S. Harnisch, H.W. Rauch and G. H. Heil. 1989. Dried natural spices in broiler rations. Arch. Geflugelk. 53, 144-150.

Windisch.W., K. Schedle, C. Plitzner and A. Kroismayr. 2008. Use of phytogenic products as feed additives for swine and poultry. J. Anim. Sci. 2008. 86 (E. Suppl.) E140-E148.

تأثير الفلفل الأحمر الحار على الأداء الإنتاجي وخصائص الأبيحة للسمان الياباني النامي. هيام سبا عبد الحليم

قسم الإنتاج الحيوانسي والثروة السمكبة ــلية النزراعة - جامعة قناة السويس

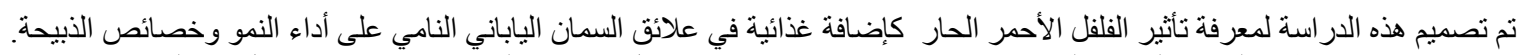

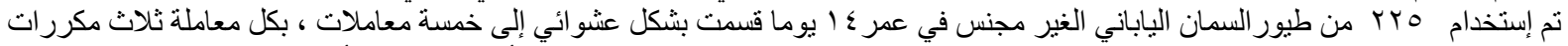

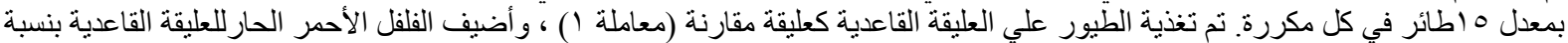

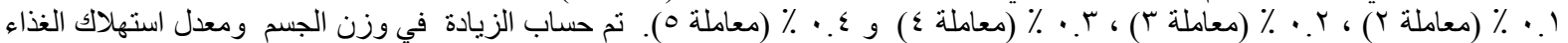
و الكفاءة التحويلية.

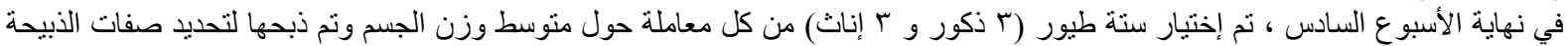

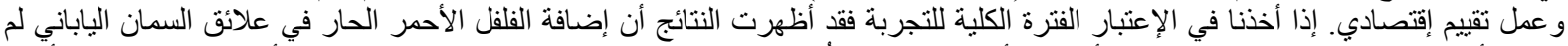

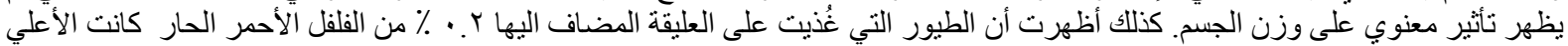

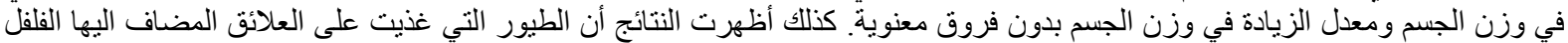

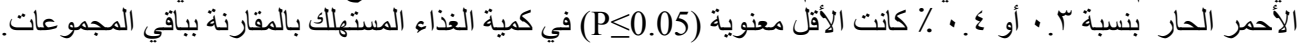

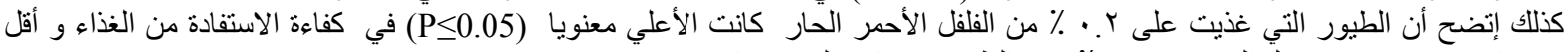

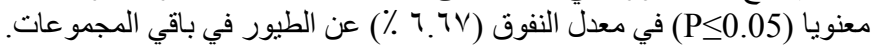

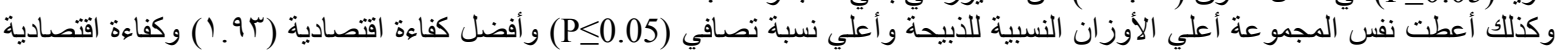

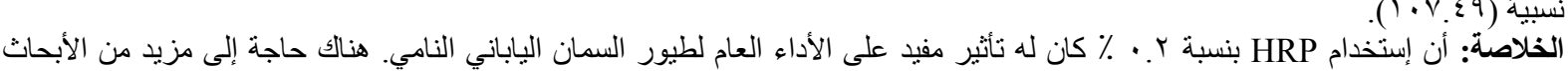
لتوضيح الآليات المرتبطة بهذه الآثار القيمة. 
Egyptian J. Anim. Prod. (2019) 56(3):139-145 